\title{
Multiple Impacts of Illegal Logging: A key to Deforestation Over the Globe
}

\author{
Fatima Khalid", Muhammad Babar Taj ${ }^{2,3,6 *}$, Asma Jamil ${ }^{1 *}$, Huda Kamal' ${ }^{1}$, Tahira Afzal ${ }^{1}$, \\ Muhammad Jamshed Iqbal ${ }^{4}$, Tahseenullah Khan ${ }^{1}$, Muhammad Ashiq ${ }^{5}$, Ahmad Raheel ${ }^{6}$, \\ Muhammad Sharif ${ }^{2}$ and Syed Ahmad Tirmizi ${ }^{6}$ \\ ${ }^{1}$ Department of Environmental Sciences, Bahria University Islamabad, Pakistan \\ ${ }^{2}$ Department of Chemistry, Islamia University Bahawalpur, Pakistan
}

${ }^{3}$ Department of Chemistry, University of Malaya, Kualalampur, Malaysia

${ }^{4}$ WWF Pakistan Firozpur road Lahore, Pakistan

${ }^{5}$ Agricultural Research Council, Pakistan

${ }^{6}$ Department of Chemistry, Quaid-e-Azam University Islamabad, Pakistan

*Corresponding author: Muhammad Babar Taj, Department of Chemistry, Quaid-e-Azam University, Islamabad, Pakistan

ARTICLE INFO

Received: 幽 August 15, 2019

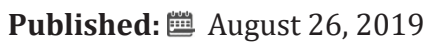

Citation: Fatima Khalid, Muhammad Babar T, Asma Jamil, Huda Kamal, Tahira Afzal, et al., Multiple Impacts of Illegal Logging: A key to Deforestation Over the Globe. Biomed J Sci \& Tech Res 20(5)2019. BJSTR. MS.ID.003519.

\begin{abstract}
This article describes the main impacts of the illegal logging activities with emphasis on the most important deforestation affected regions; Indonesia, Bangladesh, Australia, India, Peninsular Malaysia, and Pakistan. Although the discussion is concentrated on the socioeconomic, environmental and governance impacts, it must be stressed that the term deforestation is the roadmap where the environmental values, the economy, and welfare of forest-dependent communities are crushed without any kindness. Despite multiple efforts, the results in the combat of illegal logging are far from satisfactory. Furthermore, governments and businesses must implement the triple bottom line concept in order to achieve sustainability.
\end{abstract}

Abbreviations: CBD: Conservation of Biological Diversity; FDPM: Forestry Department Peninsular Malaysia; THED: Theory of Himalayan Environmental Degradation; CITES: Convention on International Trade in Endangered Species

\section{Introduction}

Deforestation is a process of wood cutting through different methods and techniques from the earth surface for different purposes. Such forest activities disturb the ecosystem and the climatic conditions of the area. Around 1.6 billion people depend on the forest resources for their necessities of life. Tropical forests are of great worth recognized at national and international standard. Most of the forests are being cut and are in the alarming situation. Deforestation and degradation of forests are gradual processes that enhance the alarming rate. Deforestation is one of the major environmental problems faced in the developing countries. If deforestation continues at an uncontrollable rate then many species will extinct Meyerson [1]. Illegal logging is a solid cause of deforestation and is generally concerned to one or more hereinafter malpractices: logging of protected species or endangered species, logging in contravention, violating rules related to volume of logging and an area of logging, or other legal specifications, logging with imitate or illicitly obtained permits, damaging trees to make them vulnerable to fell legally, actions to avoid taxations, processing wood without license and documentation, overvaluing and obtaining timber exceeding market price White [2].

Unauthorized forest activities end up with deforestation, divest local people, environmental degradation and elevate doubledealing. The value of unauthorized wood cutting is obtained by calculating the difference between the total amount of wood harvested and the amount of wood consumed. The amount of wood being harvested unofficially is ten times more than the legal wood being harvested. Royal Institute of International Affairs documented that approximately $\$ 150$ billion are utilized in global 
trade of wood products and globally for unofficial forest activities ten times more than this amount is utilized. There are different methods to estimate unofficial wood cutting which includes wood flow analysis, interview-based data, statistical comparison of import and export. The amount of unofficial wood harvesting varies depending upon the supply and demand for wood Peck [3].

\section{Ranking Scales}

According to Transparency International rank table, Indonesia comes in the 1 number of being the most corrupt country, and the level keeps rising in regard to corruption in the forest sector. The recent rise is noted down by several investigations and environment-related reports with regards to International Forestry Research Smith, et al. [4]. There are some 10 factors that need to be considered while ranking countries: the rule of law, invasiveness of government, monitoring effectiveness, market openness.

Country ranks come from 0 to 100 , more will be the rank in numbers, and progressive will be the economy, some countries names are being mentioned in this like Singapore comes in the highest number in this context. Coming towards the ranking Asia Pacific, South and Central America, and the Middle East/North Africa arrives in the same range of numbers from 57.5 to 60.0 , While Sub Sahara has the lowest number 53.7 and the highest range is being detected in North America 66.1 to 73.8. When EU countries are on the list attention was involved as countries like Estonia and Lithuania comes on 16 and 23 that isn't the truth in the case of forest-related offend Ericsson et al. [5]. It was disclosed by Environmental Investigation Agency in Honduras that there was a pile of corruption and illegalities by politicians, the State Forestry Administration, Timber companies, loggers, transporters, mayors and police. While working on Indonesia, Ghana and Cameroon same conclusions are being made. One of the main problems that arise while solving the issue of illegal deforestation was the difference of interest between State, Government and Stakeholders. After the Suharto era, Indonesia local sovereignty presented district governments immense role in the management of natural resources, aggravate forest loss Cashore, et al. [6].

\section{International Status of Deforestation Caused by Illegal} Logging and Trade

Forests are the resource that naturally regulates the climatic conditions and concentrations of $\mathrm{CO}_{2}$ in the area. Rapid industrialization and urbanization cause increased deforestation. The fast and unchecked cutting of green cover resulted in unbearable losses and caused worst disasters Petak [7]. A study on 'Illegal Logging and Related Timber Trade' reported that China depends upon all tropical forest regions and Russia for illegal timber whereas India depends on Southeast Asia. China consuming the illegal wood with a worth of USD (United States Dollar) 3295.7 annually, Vietnam of USD 767.3, India of USD 596.5, EU of USD 453.9, Thailand of USD 101.4, USA (United States of America) of USD 88.2,
South Korea of USD 22.4, Japan of USD 15.1, Malaysia of USD 12.1 and Australia of USD 1.1. The producers of illegal wood are Southeast Asia includes Myanmar, Cambodia, Indonesia and Brazil exporting illegal wood with a worth of USD 3471.4, Russian Federation of USD 1265.6, Oceania of USD 685.2, Congo Basin of USD 521.4 and South America of USD 387.1 Jianbang, et al. [8]. Illegal logging is a key to deforestation over the globe, degrading the environment and give rise to the underground market economy. Some countries are playing a remarkable role in interstate commerce for wood/ timber products. The peak producers of illegal timber are Myanmar, Cambodia, Indonesia, Brazil, Russian Federation, Oceania, Congo Basin and South America. The peak users or importers of illegal timber are China, India, EU (European Union), Thailand, USA, South Korea, Japan, Malaysia, Australia and Vietnam. China is a leading country in utilizes the illegal wood followed by Vietnam and India Marcussi [9].

\section{Cases of International Deforestation}

Indonesia: When we check the overall performance of the world with respect to the protection of forest "Indonesia" is one of the countries where this needs to be implemented the most. As the cause of a broad range of endangered species like tigers, elephants and orangutans exist in it so as a distinctive range of biological forest exist in it. But the sad reality is Agriculture Production and illegal logging is being noted to be the main culprits of change in forest cover. However, from 1990 to 2010, Indonesia had raised its forest cover from 10 to 14\%. It had been observed that even if an area had been mentioned as protected still this doesn't stop the deforestation from happening. Due to this mentioning of government as an area to be protected area, it might stop the local community for utilizing forest resources this leads to a decrease in the monitoring of that area and an increase in illegal logging activities. One of the reason formations of forest protection noted to ineffective is the cause of uncertainty in landholding or land allocation rights that leads to decline in monitoring and implementation. However, one thing was noted that in National Parks logging activates decline but that doesn't mean that such activities had completely been ended. Deforestation activities don't seem to be declined in Sumatra protected areas. However, almost $56 \%$ of deforestation had been reduced in low land areas of Kalimantan from 1985 to 2001. But the graph altered as from 1996 to 2002 around 2 million hectors forest cover was declined. This current studying was focusing upon the functional scenario of seven Indonesian forest protected areas introduced between 1999 and 2012 .

Finding of how from space to space variation has been observed in the functional behaviour of these parks. As Indonesia was a vast area with respect to the forest so the deforestation threats in it vary from region to region. Regarding the current forest data in the end effect on national average preserves has been noted which denoted that $1.1 \%$ of forest cover; decrease had been noted with corresponding to impact on individual parks extend the increase 
noted was 5.3\% but the overall Parks impact was different than national average range. Prejudice in the data may have contributed in the divergence of the determined result however it had been observed that Sebangau National Park was more efficient in working comparatively to other parks in the protection of forest cover Shah et al. [10]. Over the past Indonesian government is trying to play its role in solving out the issue of Deforestation (Illegal) for this it has followed some steps for its solution along with its trade.

While following the steps of this leads to the formation of national timber legality verification system (SVLNK), that involves an explanation of legal framework and also enhancing the involvement of stakeholders with forest sector. Private sector reacted in a positive way by promoting awareness of Deforestation (Illegal). These results identified the growing rise of the plantation with minimization in deforestation activities. Land use planning upgradation is needed along with forest conversion needed to be raised as well. Hence for the accomplishment of this activity appraisal in the number of trained officials needed. To solve out the problem of rising in corruption government needs to properly give rights of community living in these areas one way is to allocating the land to these people by the process of mapping and registration Noe, et al. [11].

Bangladesh: In Bangladesh, the forest covers use to be around $17.8 \%$. But this forest cover gets disturbed a lot due to massive deforestation which will be leading towards several problems. The study was mainly focusing on the areas of tropical moist deciduous Sal forests. Methods that were actually used for data collection are primary and secondary data, for primary data collection questionnaire surveys is used which comprises discussion with the local community, while for secondary data collection experts and literature review get used. 2 large group of forest people are used each consist of 60 people both forest dependent and independent people. The study comprises opinion from four "Range officers" and Assistant Conservator of forest in Madhupur Sal forest. At the end from the findings, it gets concluded that illegal logging is the key factor that is playing its role in the massive amount of deforestation. About $53 \%$ of dependent and $26 \%$ of non-dependent (non-ethnic) group were not capable of meeting the food requirements all the year and only $10 \%$ can make it half year. Illiteracy is observed to be responsible for deforestation as people doesn't have any other way of earning money and meeting their needs. Poverty is a major cause of deforestation and its massive amount is leading towards Illegal logging. People migrate towards Sal forest for achieving a settled and established lifestyle Fox, et al. [12].

Australia: Illegal logging is lucrative international trade at a global level related to corruption, violating human rights, enhancing criminal networks and environmental degradation. According to a study by Global Financial Integrity in 2017 declared the illegal logging activity as the third largest global criminality in cost after counterfeiting and drug trafficking Wyler et al. [13]. The total worth of timber products imported by Australia every year is near
Australian $\$ 8.1$ billion. Estimates concluded by the Department of Agriculture and Water Resources are around Australian \$800 million which may come from illegally logged wood; Nevertheless, the federal government is accepting the wood and diluting the laws and regulations to inhibit the activities causing illegal logging. The companies might not know about wood being coming from which source and consumers are in the dark that purchased the wood product are produced by legal wood. As the Australian government acknowledged that while checking for legality challenges are faced in illegal wood trade through bribery. It is common to have errorfree government documents and certifications for illegal wood. Neither the European Union nor the United States regulation admits the third-party certification in order to guarantee wood as legal Rhodes, et al. [14].

India: It was reported that $42 \%$ of the entire international trade of Roundwood and sawn wood is gained by means of illegal cutting; with a worth of rupees 427 billion. At the international level, India is considered to be the third largest importer regarding illegal wood. China is the largest consumer of illegal wood with a worth of rupees 223 billion per annum and followed by Vietnam consuming illegal wood with a worth of rupees 52 billion. The illegal wood imported by India worth rupees 40 billion, contributing around $10 \%$ of the illegal wood trade worldwide Arets, et al. [15]. A study released at a global meeting of United Nations Conservation of Biological Diversity (CBD) about 'Illegal logging and Related Timber Trade' documented that one-third of the total amount of tropical timber trade obtained illegal forest activities Izursa et al. [16]. Due to legality verification of timber is required by other developed countries the salesmen switched their traffic timber trade to countries like China and India; where lack of laws is implemented, and economic growth demands illegal timber. The largest consumers of illegal wood; China, Vietnam and India increased the consumption by $50 \%$ from $2006-2013$. India imports illegal timber from Southeast Asia Publishing and Centre [17].

Peninsular Malaysia: The study summarizes the trends and present status of illegal logging in Peninsular Malaysia. The data collected was based on governmental and non-governmental sectors including the Forestry Department Peninsular Malaysia (FDPM), International Tropical Timber Organization (ITTO) and Food and Agriculture Organization (FAO). The gathered data was statistically analyzed to get cogency of the relationship between legal and illegal log production. The study showed increasing trends of illegal logging. $18 \%$ of the total wood cutting per annum is gained through illegal activities. There is an inverse relationship between the legal and illegal log obtained. The main cause of illegal logging in Peninsular Malaysia was never clearly spotted but according to some NGOs illegal logging in Peninsular Malaysia is caused due to lack of law enforcement which gave rise to corruption within forest authorities Shanmugam [18].

Pakistan: In Pakistan, between the rate of consumption and supply, there exists a fearsome gap. Here's a recording of past and 
present wood consumption recording in 1993 wood supply was $18 \%$ insubstantial and in 2013, this rise to a quarter of average consumption. About the other recordings, its validity is not evident. Due to illegal logging timber was taken away in a massive ratio from the public forest. There was theory also exist about Himalayan forest also that is Theory of Himalayan Environmental Degradation (THED). It explained that in the Himalayan region due to overpopulation pressure gets building up on the mountain ecology. The other important factor was that socioeconomic pressure was building up as urbanization is raising more lowland areas are converting into cities and so the demand is clashing with the supply of wood Penh [19]. The decrease in a number of the forest is also been observed as the government didn't succeed in the formation of a relevant institutional system for forest management. Another main reason for the decrease in a number of the forest is due to the closeness of private forest contractors and forest officials which contributed towards illegal logging activities.

Pakistan has strived to overcome "Timber Mafia" which basically means groups or individuals who illegally cut trees and sell them for their benefit without a warrant. At the time of independence Pakistan had $7 \%$ green cover but after Bangladesh separation in 1971 , it was reduced to less than $5 \%$. The forest cover (\% of land cover) calculated by World Bank in Pakistan was 1.91 as of 2015. The top value of forest cover in Pakistan was 3.28 in 1990 and the bottom value was 1.91 in 2015 over the past 25 years. Pakistan is now left with only $2-5 \%$ of its forest cover and so is at a critical point. Islamabad because of the presence of Margalla Hills National Park is one of the lush green capitals which is facing deforestation. Bare lots and arboreous areas are being chopped off leaving behind only twisted yellow ankle-high sapwood. The amount of economy used in the underground market economy at the global level is \$1.81 trillion includes $\$ 7$ billion for illegal logging. Pakistan contributes about $\$ 6.53$ billion in the underground market economy including $\$ 782$ million for illegal logging. These values are based on annual illegal wood harvesting Nazir et al. [20].

\section{Main Impacts}

\section{Socio-Economic Impacts}

In many parts of the world eradication of forests is causing the shortage of ownership rights to forest communities and a result of which huge amount of pressure is being settled on native populations which will force them to shift to more densely populated areas. It is a fact that the conflict between wood industry interests and local communities are multiplied due to extremely uncertain land ownership relations Izursa et al. [16].

Several areas in the world are practicing illegal logging and cause the destruction of forests. The socio-economic impacts caused by large-scale illegal logging activities are listed hereinafter: desertification, drought, loss of traditional cultures and increased runoff, economic loss, loss to soil fertility, human rights violation and increased ratio of homeless people Reboredo [21]. The social impact is a broad category of impacts. The most important is that it disrespects the law and rule of a nation and related to corruption. It weakens the rights of property holders of the forest communities. Lack of identification of land use and resource use is involved causing negative impacts on local communities. As these forests are the homelands of a great number of people and threaten their lifestyle and needs which give rise to conflicts (TEFSO).

The profit generated by these illegal activities may fund national or regional conflicts. This is practiced in countries such as Myanmar, Cambodia, Liberia, Democratic Republic of Congo and many areas around the world (TEFSO). In Indonesia conflicts related to timber may cause damage to property, injuries and even deaths. The fastgrowing economy of China is imposing great pressure on wood consumption by means of the huge amount of wood being imported and increasing plantation Reboredo [20].The economic impacts are that when trees are cut down without permits and then smuggled abroad the financial loss is faced by government in different ways. These losses are in the form of taxes and duties that are not paid by smugglers or in another word through corruption (TEFSO). The illegal logging also disturbs the timber markets in a way by lowering down the timber prices which leads to unsustainable forest management (TEFSO). Some studies declare that labours hired for illegal logging are paid more in comparison to other labour force. The illegal logging estimation reported by World Bank in 2006 is approximately US $\$ 15$ billion annually which includes the loss of US $\$ 10$ billion by legal forest industry and the US $\$ 5$ billion by the government in revenues. The timber product worth at global level has reduced by a great percentage due to illegal logging Reboredo [20].

\section{Environmental Impacts}

High level of deforestation is taking place due to illegal logging in the world. At a huge catastrophic level, illegal logging activity is taking place which are converting the forests into grasslands and a considerable decline in plant and animal species are also observed. In the protected areas illegal logging practices can cause the rare plant and animal species to become threatened Reboredo [20]. Destructive floods, damaged landscapes, polluted air and drinking water can result due to deforestation. And the area will become more exposed to climate change Kolstad et al. [22,23]. Deforestation has its wide range of impacts in respect to biodiversity, which leads also towards the extinction of species due to the falling in the amount of tree count. There is an estimated $30 \%$ of remaining habitat cover in regards with the extinction threshold Tacconi [24].

It is found that approximately 420 million tons of carbon are annually present in the industrial roundwood taken off from the global forests. Some amount of this carbon in the industrial roundwood is stored in products and it remains there for a prolonged period whereas much of the carbon is send back quickly to the atmosphere. Peatlands are being degraded in Indonesia because of deforestation (legal and illegal), frequent fires and drainage which result in an extensive release of peat soil carbon 
into the air. A study was carried out which by using remote sensing data and field inventory found out that the rise in the groundwater level inside the drained peat swamp forest could decrease the emission of $\mathrm{CO}_{2}$. China in 1998 faced immense flooding along pearl, Yangtze and Songhua rivers. Due to which thousands of people died and millions became homeless. Though the cause was heavy rainfall, what basically triggered the disaster was huge deforestation and decreased control of water runoff. 1800 people were killed in a landslide in the Quezon Province of Philippines in 2004. It was found that deforestation played a major role in this disaster. The Convention on International Trade in Endangered Species (CITES) put forward the tree species which are found to be in danger are Afrormosia (Pericopsis elata) in Africa, bigleaf mahogany (Swietenia macrophylla) in the Americas and Ramin (Gonystylus spp.) in Southeast Asia. In Honduras, the species at risk are Tropical Cedar and Mahogany Reboredo [20]. Tanjung Puting National Park in Indonesia is considered to be Southeast Asia's biggest protected area of swamp forest. The tree species it contains are Ramin (Gonystylus spp) and Meranti (Shorea spp.) and the most popular Orangutan.

A study was conducted by EIA/Telepak which found out several illegal logging cases dictated by the authorities themselves who captured the Ramin loadings and found out Ramin factories which were operating without a license. According to the Indonesian government, 37 out of 41 national parks in Indonesia are facing illegal logging. The Sumatran rhino (Dicerorhinus sumatrensis) has reduced to very less in number, less than 40 individuals are found to remain in Peninsular Malaysia and the state of Sabah. The Northern Sierra Madre mountain range of the Philippines contains "The last great forest" which contains two endangered animals found in the world the Philippine crocodile and the Philippine eagle and magnificent tree species this is because of the spread of deforestation. In Sumatra and Borneo in 1997 and 1998 massive fires were spread which were caused largely due to plantation and timber companies. In the province of East Kalimantan, four Million hectares of land was destroyed about 176 firms were indicted for intentionally setting fires Reboredo [20].

\section{Governance Impacts}

Forest department needs to work on controlling the crime regarding forest and also should check and balance the problems which people living in forest areas face making their equitable distribution on taxes, and also taking care of the part they play regards to the forest. In Asia Pacific region illegal logging and deforestation are been a forever recognizable environmental crime. What's more obvious is Indonesian forest ministry has condemned Malaysia and China for giving privileges to wood industries which is unfair by taking illegal wood. The wars in Cambodia started in 1970's and become more enlarged till the early 1990's in the Congo area, so in 2001 UN used the phrase "Conflict timber" which was associated with these civil wars. Timber conflicts are spread worldwide some other examples are Indonesia, Burma, Philippines, Liberia. For financing the military operations in Liberia its president Charles Taylor apply such conflict timber to destabilize Guinea, Sierra Leone, and Ivory Coast. In the last decade around 200 forest rangers died in the Democratic Republic of Congo because of Charcoal trade at over US \$28 M and its threatening habitat of humans along with gorillas. Due to the following things Timber conflict arises:

I. When military forces and government get involved

II. Some fewer chances also arrive due to economic issues

III. When land and timber resources are not certain

IV. When there are fewer possibilities of recourse in the implementation of the legal system Sheikh, et al. [24].

\section{Role of Media}

Media highlighted this issue in a positive way by increasing public awareness on this matter and also the trade of wood done by illegal logging. But one thing to note down in illegal logging manner is highlighting the problems doesn't mean that change is going to get occur straightway but notifying the problem towards people is important. Media assessment helps to find out how this issue is being communicated in the various country or the actions being taken for it. For research both international and national media being studied from 2009-12. National media source studies get done by using three online sources related to illegal logging information. International media sources were accessed by online media database Factiva. In the end, the results suggested that from 2001 major increase observed in 2007 than decline happens. Some increase did get observed in 2010 that gets communicated by the number of articles being written down. In international media mostly, articles from 2010-12 are being written regarding palm oil production and decline, forest conversation not specifically mentioning illegal logging. This decline regarding illegal logging also gets plotted in national media as well the only rise observe is in 2008 Janssen, et al. [25,26].

\section{Conclusion}

This review focuses on cases of deforestation in term of illegal logging at the international level and their Socio-economic, environmental and political impacts. It points out to the factor that we need to check our protection system otherwise in future the situation will turn out worst. This study interacts the reader that are trying to make conservation policy it will help in checking the past and present forest cover data. It will help in observing the encroachments that are been building around the National Park in various countries.

\section{Conflict of Interest}

The authors declare that they have no conflict of interest. 


\section{Acknowledgement}

Authors are thankful to higher Bahria University Islamabad, Pakistan for providing a platform for the study.

\section{References}

1. Meyerson FA (2004) Population growth and deforestation: a critical and complex relationship. Population Reference Bureau, Washington, DC.

2. White R (2018) Transnational Environmental Crime and Global Security. Transnational Crime and Global Security 2: 181.

3. Peck T (2001) The international timber trade, Elsevier.

4. Smith J, K Obidzinski, S Subarudi, I Suramenggala (2003) Illegal logging, collusive corruption and fragmented governments in Kalimantan, Indonesia. International Forestry Review 5(3): 293-302.

5. Ericsson K, LJ Nilsson (2004) International biofuel trade-a study of the Swedish import. Biomass and Bioenergy 26(3): 205-220.

6. Cashore B, MW Stone (2012) Can legality verification rescue global forest governance? Analyzing the potential of public and private policy intersection to ameliorate forest challenges in Southeast Asia. Forest policy and economics 18: 13-22.

7. Petak WJ (1985) Emergency management: A challenge for public administration. Public Administration Review 45: 3-7.

8. Jianbang G, P Cerutti, M Masiero, D Pettenella, N Andrighetto et al. (2016) Quantifying illegal logging and related timber trade, International Union of Forest Research Organizations (IUFRO), Vienna, Austria.

9. Marcussi JC (2016) The Brazilian Amazon Timber Industry and the International Mechanisms of Timber Trade Control-Combating Illegal Logging and Associated Trade.

10. Shah P, K Baylis (2015) Evaluating heterogeneous conservation effects of forest protection in Indonesia. Plos one 10(6): 0124872.

11. Noe RA, JR Hollenbeck, B Gerhart, PM Wright (2006) Human resource management, China People's University Press.

12. Fox J, M Mustafa, BR Bushley, SM Brennan, L Durand (2013) Connecting communities and conservation: co-management initiatives implemented by IPAC in wetlands and forests of Bangladesh, Dhaka, Bangladesh: Integrated Protected Area Co-Management in Bangladesh.

13. Wyler LS, PA Sheikh (2013) International illegal trade in wildlife: threats and US policy, Biblio Gov.

\section{ISSN: 2574-1241}

DOI: 10.26717/BJSTR.2019.20.003519

Muhammad Babar Taj, Asma Jamil. Biomed J Sci \& Tech Res

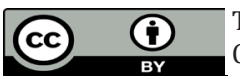

This work is licensed under Creative

Commons Attribution 4.0 License

Submission Link: https://biomedres.us/submit-manuscript.php
14. Rhodes WM, EP Allen, M Callahan, I Abt Associates and US America (2006) Illegal Logging: A Market-Based Analysis of Trafficking in Illegal Timber, Final Report.

15. Arets E, P Van der Meer, C Verwer, G Hengeveld, G Tolkamp, et al. (2011) Global wood production: assessment of industrial round wood supply from forest management systems in different global regions. Alterra Wageningen UR.

16. Izursa JL, DR Tilley (2015) Dynamic Eco-industrial Model of Forest Rich Developing Nations: Application to the Bolivian Forestry Sector and National Economy. Journal of Environmental Accounting and Management 3(1): 1-22.

17. Publishing 0, OD Centre (2013) Economic Outlook for Southeast Asia, China and India 2014: Beyond the Middle-Income Trap, OECD Publishing.

18. Shanmugam S (2015) The effect of trade related environmental measures on the forest sector and timber trade of Peninsular Malaysia, University of Nottingham.

19. Penh P Konrad-Adenauer-Stiftung.

20. Nazir N, LS Olabisi (2017) Illegal Logging and Wood Consumption: Estimation and Projection of Illegal Wood Harvesting in Pakistan through System Dynamics. Pakistan Journal of Commerce \& Social Sciences 11(2).

21. Rebored F (2013) Socio-economic, environmental, and governance impacts of illegal logging. Environment Systems and Decisions 33(2): 295-304.

22. Kolstad C (2011) Intermediate Environmental Economics: International Edition. OUP Catalogue.

23. Forman R (2014) Land Mosaics: The ecology of landscapes and regions (1995), Springer.

24. Tacconi L (2007) Decentralization, forests and livelihoods: theory and narrative. Global environmental change 17(3): 338-348.

25. Sheikh PA, RW Gorte, J Sidener (2008) Climate Change and International Deforestation: Legislative Analysis, Congressional Research Service.

26. Janssen TA, GK Ametsitsi, M Collins, S Adu Bredu, I Oliveras, et al. (2018) Extending the baseline of tropical dry forest loss in Ghana (1984-2015) reveals drivers of major deforestation inside a protected area. Biological Conservation 218: 163-172.

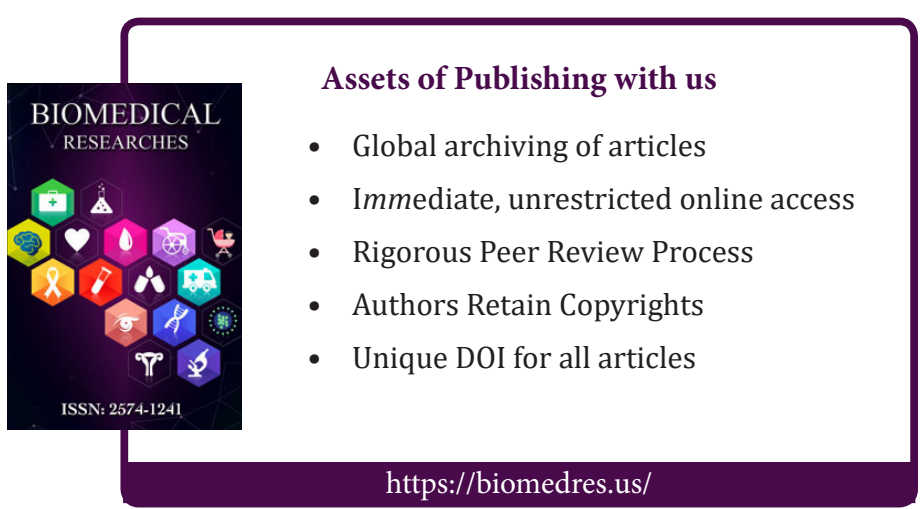

